\title{
Analisis Perkembangan Sosial pada Anak Bilingual di Abad 21
}

\author{
Aulia Annisa \\ STAI Syekh H. Abdul Halim Hasan Al-Ishlahiyah Binjai, Sumatera Utara, Indonesia \\ INFORMASI \\ ARTIKEL \\ Artikel Histori: \\ Diterima : \\ $21 / 11 / 2020$ \\ Direvisi : \\ 12/12/2020 \\ Diterbitkan: \\ 20/01/2021

\section{Keywords: \\ Bilingual, \\ Social \\ development, Early childhood,} \\ Kata Kunci: \\ Bilingual, \\ Perkembangan \\ sosial, \\ Anak usia dini

\section{DOI:} \\ https://doi.org \\ $\angle 10.46963 / \mathrm{mas}$ \\ h.v4i01.223 \\ Korespondensi \\ Penulis: \\ Aulia Annisa \\ auliahamdan19 \\ @gmail.com

\begin{abstract}
Communication is an important requirement in order to adapt to the broad social environment in the 21st century. One of the efforts made is the use of two languages (bilingual) in everyday life. However, parents unconsciously put children into a world with language development tasks that are more complex than the competencies that children should have. This of course will affect social development and children's ability to interact with the environment. This study analyzes the use of bilinguals in terms of children's social competence and social behavior. The research method uses literature studies by analyzing 20 books and scientific articles related to bilingualism and children's social development. The data analysis technique used content analysis related to the phenomena, causes and effects of social development in children using bilinguals. The results of the analysis show that the use of bilingual children has a positive and negative side to the child's social development. The positive thing is that bilingual children can easily adapt outside their social environment as a means of communication. There will be a sense of pride in the child because he can master more than one language. But the negative thing is, some of the bilingual children will find it difficult to understand new concepts in a different language, so they often feel depressed. In addition, there is a gap between children and their social environment.
\end{abstract}

\section{Cara mensitasi artikel:}

Annisa, A. (2021). Analisis Perkembangan Sosial pada Anak Bilingual di Abad 21. Mitra AshShibyan: Jurnal Pendidikan dan Konseling, 04(01), 31-46. https://doi.org/10.46963/mash.v4i01.223 


\section{PENDAHULUAN}

Bahasa merupakan alat komunikasi yang digunakan manusia untuk berinteraksi sehingga pesan yang dimaksudkan dapat dimengerti. (Hurlock, 1978) menyatakan bahwa bahasa mencakup setiap sarana komunikasi dengan menyimbolkan pikiran dan perasaan untuk menyampaikan makna kepada orang lain dalam bentuk yang luas seperti: tulisan, berbicara, bahasa simbol, ekspresi wajah, isyarat, pantomin dan seni. Bahasa ini terus berkembang diawali dengan bahasa pertama individu.

Setiap manusia mengenal bahasa pertamanya melalui proses sosialisasi dalam lingkungan keluarga. Pakar bahasa, Noam Chomsky dalam (Santrock, 2002) yakin bahwa manusia terikat secara biologis untuk mempelajari bahasa pada suatu waktu tertentu dan dengan cara tertentu sesuai dengan bahasa yang didengar anak sejak kecil. Bahasa inilah yang nantinya akan dikuasai oleh anak ketika berinteraksi dengan lingkungannya, yang disebut sebagai bahasa ibu. Bahasa Indonesia umumnya merupakan bahasa ibu bagi anak Indonesia.

Kemampuan berbahasa asing juga menjadi salah satu kebutuhan bagi masyarakat selain bahasa Indonesia. Hal ini dikaitkan dengan globalisasi yang identik dengan tidak ada batasan bagi negara-negara di dunia yang membutuhkan suatu bahasa komunikasi universal. Tanpa adanya ketrampilan yang baik, sangat sulit bagi seseorang untuk mendapatkan dan mempertahankan pekerjaannya. Tingginya tuntutan dan standar yang harus dipenuhi ketika memasuki dunia kerja membuat orang tua juga semakin banyak menuntut anak-anak mereka yang masih dalam dunia sekolah (Gunarsa, 2004). Salah satu cara membantu perkembangan anak selain di rumah bersama orang tua adalah dalam pemilihan sekolahnya (Annisa \& Sutapa, 2019). Melalui sekolah, anak akan menemukan banyak reverensi dalam tumbuh kembang sosial dan bahasanya.

Di Indonesia, bahasa asing yang paling populer dan banyak diminati untuk dikuasai masyarakat ialah bahasa Inggris yang mana telah dijadikan sebagai bahasa universal di dunia. Kemampuan berbahasa asing terutama berbahasa Inggris, dijadikan prasyarat kesuksesan seseorang di masa depan. Asumsi ini membuat berbagai institusi pendidikan menyediakan pendidikan bahasa asing bagi perkembangan bahasa anak, 
termasuk menyediakan program bilingual (Sutiyoso dalam Purba et al., 2016).

Bilingual adalah kemampuan menggunakan dua bahasa. Anak yang memiliki kemampuan bilingual memahami bahasa asing dengan baik seperti halnya pemahaman anak terhadap bahasa ibunya dalam empat ketrampilan berbahasa, yaitu mendengarkan, berbicara, membaca dan menulis (E. B. Hurlock, 1993).

Salah satu kelebihan terkait penggunaan bilingual dikemukakan oleh para ahli syaraf yang meneliti hubungan antara belajar bahasa asing dengan perkembangan otak. Kesimpulan dari berbagai penelitian yang telah dilakukan menunjukkan pengaruh mempelajari bahasa asing dan keuntungannya bagi perkembangan otak, yakni perkembangan yang lebih pesat dalam proses kognitif, kreativitas dan divergent thinking dibandingkan dengan anak-anak monolingual (Purba et al., 2016).

Sekolah-sekolah yang menyediakan program bilingual berarti menggunakan dua bahasa di dalam kegiatan pendidikannya. Adapun bahasa yang sering digunakan pada sekolah bilingual di Indonesia adalah bahasa Indonesia dan bahasa Inggris dalam kegiatan belajar mengajar setiap hari. Ada pelajaran yang diajarkan dengan menggunakan bahasa Inggris, dan ada pula yang dengan bahasa Indonesia (Gunarsa, 2004). Penerapan konsep bilingual ini membuat pihak sekolah dan orang tua berharap anak akan lebih mahir dan menguasai Bahasa Inggris (Sutiyoso dalam Purba et al., 2016). Banyak penelitian tertarik untuk meneliti bagaimana dampak dari penerapan bilingual ini. Ada penelitian yang mengemukakan hasil negatif dan ada pula yang positif (Gunarsa, 2004).

Dampak pembelajaran dua bahasa yang menimbulkan konsep pemahaman yang tidak jelas pada anak. Masalah ini terjadi karena bahasa Indonesia dengan bahasa Inggris berbeda secara struktural dan tata cara aturan kalimat (Sutiyoso dalam Purba et al., 2016)). Anak bilingual cenderung tidak dapat menguasai satu bahasa secara keseluruhan oleh karenanya menyebabkan anak berbicara dengan bahasa yang bercampur antara bahasa ibu dengan bahasa asing (Genesse dalam Gunarsa, 2004)). Permasalahan perkembangan intelektual secara makro kemudian sangat bergantung juga pada banyak faktor, salah satunya adalah pendidikan yang mampu memaksimalkan potensi intelektual. Begitu juga dengan perkembangan sosial khususnya kompetensi dan perilaku anak. 
Penelitian tentang program imersi bahasa Inggris menunjukkan bahwa anak-anak dalam program immersion prasekolah sering kehilangan bahasa rumah mereka, dikarenakan mereka lebih senang menggunakan bahasa Inggris, dapat mengembangkan komunikasi permasalahan dengan keluarga mereka, dan pengalaman prestasi akademik yang lebih rendah dalam bahasa Inggris (Hakuta, Kenji; Butler, Yuko Goto; Witt, 2000).

Berdasarkan berbagai penjelasan diatas maka peneliti melakukan analisis bagaimana gambaran kompetensi dan perilaku sosial pada anak yang mengikuti sekolah bilingual, khususnya masa anak usia dini yang dipersiapkan untuk memasuki masa sekolah dan dunia sosial lebih luas serta masa emas untuk belajar dan berinteraksi dengan teman sebaya. Tindak lanjut dari analisis ini akan terlihat apakah ada pengaruh antara bilingual terhadap perkembangan sosial anak usia dini.

\section{METODE PENELITIAN}

Penelitian ini menggunakan pendekatan studi literatur. Secara teknis, peneliti melakukan serangkaian kegiatan yang berkenaan dengan metode pengumpulan data pustaka, membaca dan mencatat serta mengolah bahan penelitian yang relevan dengan permasalahan penelitian. Subjek dalam penelitian ini berupa 20 buku dan artikel ilmiah yang dianalisis terkait perkembangan sosial anak pengguna bilingual.

Data berupa referensi dari berbagai karya ilmiah yang relevan kemudian dianalisis dengan cara melakukan analisis isi (content analysis). Analisis isi merupakan pembahasan mendalam terhadap isi suatu informasi tertulis atau tercetak dalam media massa. Beberapa hal yang dianalisis dalam penelitian ini berupa fenomena, penyebab dan efek perkembangan sosial pada anak pengguna blingual.

\section{HASIL DAN PEMBAHASAN}

\section{Bilingual di Abad 21}

Awal abad ke-21 yang dikenal dengan era milenial langsung mengubah seluruh komponen kehidupan termasuk dunia anak. Anakanak yang tumbuh dan berkembang pada abad ini secara tidak langsung memiliki pola perkembangan yang sangat kompleks dilihat dari segala macam aspek perkembangannya (Annisa \& Sutapa, 2019). Konsep umum bilingualisme adalah digunakannya dua buah bahasa oleh seorang penutur dalam pergaulannya dengan orang lain secara bergantian (Chaer \& Agustina, 1995).

34 mitra Ash-Shibyan: Jurnal Pendidikan dan Konseling | Vol. 04, No. 01 (2021) Licensed under CC-BY-SA (c) (1) () 
Bilingualisme berkaitan erat dengan pemerolehan bahasa kedua. Pemerolehan bahasa berkaitan erat dengan bagaimana anak memperoleh kata, makna, struktur, dan pragmatik. Itu tidak lain berhubungan dengan proses yang terjadi dalam mind dan sikap anak. Menjadi bilingual atau multilingual sejak dini dengan kata lain seorang anak mempunyai pengalaman proses pemerolehan kata, makna, struktur, dan pragmatik yang lebih kompleks sejak dini dibandingkan dari mereka yang hanya monolingual.

Secara umum dan dalam logika sederhana, bilingualisme dini membawa anak dalam pengalaman dua bahasa yang berbeda. Pengalaman dua atau lebih bahasa sejak dini ini pasti memberikan pengaruh yang berbeda dari pengalaman satu bahasa. Thomas dan Collier dalam (Szecsi, 2005) menguraikan tiga orientasi untuk memahami cara kerja bahasa dalam masyarakat beragam Bahasa. Dalam konteks ini, bahasa dapat dirasakan sebagai masalah, sumber daya, atau hak. Bahasa sebagai orientasi masalah muncul dari pemahaman defisit minoritized, bahasa non-dominan dan masyarakat linguistik. Bahasa rumah dipandang sebagai penghalang untuk pencapaian pendidikan dan mobilitas sosial karena tidak menahan modal linguistik yang cukup kekuatan yang dibutuhkan untuk menjadi nilai sosial dan budaya.

Dari orientasi ini, masyarakat mengadopsi kebijakan bahasa dan praktek yang bertujuan untuk memfasilitasi mengajar dan belajar bahasa dominan secepat mungkin tanpa membuat ketentuan untuk mempertahankan bahasa rumah anak ketika belajar bahasa kedua berarti kehilangan yang pertama (Fillmore, 2012).

Espinosa (2013) telah banyak menulis tentang mitos yang terkait dengan bilingualisme dan pendidikan bilingual di tahun-tahun awal dan mencatat bahwa kepercayaan umum di Indonesia adalah bahwa perendaman total bahasa Inggris merupakan cara yang paling efektif untuk memastikan bahwa anak-anak menjadi penutur bahasa Inggris mahir .

Fenomena tentang penggunaan bahasa secara tidak langsung berkaitan dengan aspek lain dalam perkembangan anak. Gejala yang muncul pada beberapa anak di berbagai bagian dunia dalam pengalamannya menggunakan bilingual dalam berkomunikasi dikaji dari sudut pandang yang berbeda yakni kompetensi dan perilaku sosial anak dalam berinteraksi dengan orang lain di lingkungan sosialnya. 


\section{Perkembangan Sosial Anak}

\section{a. Kompetensi Sosial}

Pellegrini dan Glickman (dalam Tarsidi, 2009) mendefinisikan kompetensi sosial pada anak sebagai suatu derajat dimana anak dapat beradaptasi pada lingkungan sekolah dan rumahnya. Kompetensi sosial merupakan dasar dimana harapan akan interaksi dengan orang lain terbangun dan anak mengembangkan persepsinya kepada perilakunya sendiri. Selain itu, kemampuan dalam melakukan percakapan mengambil peran yang penting dalam interaksi. Anak yang sukses secara sosial ditemukan memiliki kemampuan untuk berkomunikasi secara jelas dan responsif kepada lawan bicaranya (Burleson dalam Purba et al., 2016).

Kompetensi sosial menurut (Clikeman M, 2007) adalah sebuah kemampuan untuk mengambil perspektif orang lain dalam suatu situasi dan belajar dari pengalaman masa lalu, kemudian mengaplikasikannya. Kemampuan untuk merespon ini tergantung pada kemampuan komunikasi yang dimiliki anak dan interaksi dengan orang lain yang menggunakan bahasa dan komunikasi non verbal. (Clikeman M, 2007) juga menuturkan elemen-elemen dari kompetensi sosial tersebut, yakni: (1) bahasa dan kemampuan berkomunikasi, (2) kemampuan secara akurat mengirim dan menerima pesan emosional, (3) kemampuan untuk belajar, (4) kemampuan untuk memahami perspektif orang lain, (5) kemampuan untuk mengatur perilakunya sendiri, (6) kemampuan untuk bekerja sama dengan orang lain.

Kompetensi sosial merupakan salah satu jenis kompetensi yang penting dan harus dimiliki oleh setiap anak. Bermain dengan teman sebaya pada usia 4-6 tahun merupakan pengembangan kompetensi sosial anak (Gunarsa, 2004). Anak yang memiliki kompetensi sosial tampak lebih mudah untuk menjalin relasi yang baik dengan orang lain. Selain itu, Piaget (dalam Tarsidi, 2009) juga mengemukakan bahwa interaksi dengan teman sebaya merupakan satu sumber utama perkembangan sosial maupun kognitif, khususnya perkembangan "role taking" dan empati yang merupakan salah satu elemen dari kompetensi sosial.

Tokoh psikososial Erikson (dalam Purba et al., 2016) juga menyatakan bahwa masa anak-anak tengah (middle childhood) 
merupakan masa emas untuk belajar. Perkembangan bahasa anak juga lebih berkembang dan berfikir dengan konsep operasional konkrit. Hubungan sosial anak juga lebih ditekankan pada teman sebaya melalui proses bermain. Namun, tidak semua anak dapat bersosialisasi dengan baik pada lingkungannya. Anak-anak yang tidak mampu bersosialisasi atau bekerja sama dengan baik akan lebih susah untuk diterima di lingkungan teman sebayanya dan anak juga akan menunjukkan kompetensi sosial yang buruk dengan lingkungannya (Putallaz, M., \& Sheppard, 1995). Oleh karena itu, kemampuan anak dalam besosialisasi dengan lingkungannya sangat diperlukan sehingga merekan dapat diterima oleh lingkungan sosialnya.

Dalam perbedaan penting lainnya (McFall, 1982) menekankan perbedaan antara keterampilan sosial dan kompetensi sosial. (McFall, 1982) mengkonseptualisasikan keterampilan sosial sebagai perilaku spesifik yang dibutuhkan untuk melakukan tugas kompeten. Di sisi lain, kompetensi sosial adalah istilah yang lebih umum dan evaluatif. Didalam Kerangka kerja, seseorang dinilai kompeten secara sosial ketika dia menunjukkan kinerja yang memadai pada tugas sosial tertentu. (McFall, 1982) menekankan terhadap pendekatan berbasis sifat dengan kompetensi sosial, ia mengatakan bahwa kompetensi sosial tidak ada dalam diri seseorang dan juga menyarankan kompetensi itu.

Dalam segala situasi sosial, anak hanya akan mampu berkompeten pada satu situasi sosial saja. Keterampilan sosial individu berkontribusi terhadap keseluruhan sosial kompetensi, namun tidak ada satu perilaku pun yang cukup untuk kompetensi tersebut. (Elliot \& Gresham, 1987) juga menempatkan keterampilan sosial di bawah konstruksi yang lebih luas dari kompetensi sosial, menunjukkan bahwa kompetensi sosial termasuk keterampilan sosial dan perilaku adaptif lainnya (mis. fungsi independen, fisik pengembangan, pengarahan diri sendiri, tanggung jawab pribadi, dan keterampilan akademik fungsional). Vaughn et al. (1990) mengidentifikasi empat komponen kompetensi sosial yaitu: keterampilan sosial yang efektif, tidak adanya maladaptif perilaku, hubungan positif dengan orang lain, dan akurat kognisi sosial. 


\section{b. Perilaku Sosial}

Definisi selanjutnya melibatkan keterampilan penggambaran sosial dengan istilah perilaku. Menggunakan definisi perilaku, keterampilan sosial dianggap sebagai situasi perilaku spesifik yang lebih mungkin terjadi diperkuat dan cenderung tidak dihukum (Elliot \& Gresham, 1987). Perilaku sosial termasuk keterampilan sosial adaptif dan perilaku lainnya yang mempengaruhi fungsi sosial (Matson et al., 2009). Jenis definisi ini biasanya digunakan dalam terapi perilaku dan literatur analisis perilaku terapan (Gresham et al., 2006).

Mengenai pengukuran, peneliti memanfaatkan definisi perilaku keterampilan sosial untuk pengamatan perilaku dalam setting tertentu. Definisi perilaku tampaknya memiliki kelebihan atas definisi penerimaan teman sebaya karena lebih spesifik, perilaku, dan konsekuensinya dapat didefinisikan dan ditargetkan untuk perawatan (Elliot \& Gresham, 1987). Namun, Gresham et al.(2006) menunjukkan definisi perilaku itu juga terbatas tidak ada mekanisme untuk memastikan yang ditargetkan keterampilan sosial secara sosial signifikan atau berhubungan dengan hasil sosial penting. Artinya, perilaku yang dipilih oleh peneliti atau dokter mungkin tidak terkait dengan hasil penting karena Perilaku sering diidentifikasi secara intuitif dan bukan Secara empiris (Han \& Goleman, Daniel; Boyatzis, Richard; Mckee, 2019).

Perilaku sosial anak akan muncul saat berada di lingkungan sosialnya. Lingkungan sosial anak terdiri dari keluarga, sekolah, teman sejawat, dan masyarakat. Aspek sosial di dalam lingkngan anak sangat berpengaruh terhadap perilaku yang muncul pada diri anak baik itu pada anak monolingual ataupun bilingual. Di kaji dari segi pengguna bilingual terhadap lingkungan sosialnya tentu memiliki pengaruh berbeda dan lebih bervariasi terhadap perilaku yang muncul pada diri anak.

Tabel 1. Elemen Perkembangan Sosial Anak

\begin{tabular}{ll}
\hline \multicolumn{1}{c}{ Elemen } & \multicolumn{1}{c}{ Aspek yang dianalisis } \\
\hline Kompetesi Sosial & $\begin{array}{l}\text { Bahasa dan kemampuan berkomunikasi } \\
\text { Kemampuan secara akurat mengirim dan menerima } \\
\text { pesan emosional }\end{array}$ \\
& Kemampuan untuk belajar
\end{tabular}

38 mitra Ash-Shibyan: Jurnal Pendidikan dan Konseling | Vol. 04, No. 01 (2021) Licensed under CC-BY-SA (c) (1) () 


\begin{tabular}{ll} 
& Kemampuan untuk memahami perspektif orang lain \\
\hline Kemampuan untuk mengatur perilakunya sendiri \\
\hline Kemampuan untuk bekerja sama dengan orang lain \\
\hline Kerilaku Sosisal & Keluarga \\
\hline Sekolah \\
\hline Teman Sejawat \\
Masyarakat \\
\hline
\end{tabular}

Perkembangan sosial dalam penelitian ini difokuskan pada kompetensi sosial dan perilaku sosial yang muncul pada anak pengguna bilingual. Berbagai elemen perkembangan sosial anak dijadikan sebagai instrument dalam melalukan analisis isi. Analisis yang dilakukan bertujuan untuk menemukan konsep tentang pengaruh dari penggunaan bilingual terhadap perekembangan sosial anak.

Faktor yang Mempengaruhi Perkembangan Sosial pada Anak Bilingual Konsep bilingual dalam kehidupan sehari hari memberikan perhatian yang sama untuk mengajar kedua bahasa itu penting tidak hanya untuk keberhasilan program tetapi untuk hasil siswa juga. Identitas program bahasa ganda muncul dari komponen budaya mereka dan status mereka dalam sekolah. Entah program disambut dan sangat dihargai, atau mereka dianggap sebagai sesuatu yang eksternal, embel-embel asing bagi sekolah. Dalam kasus terakhir, nilai intrinsik mereka belum tentu acknowl- bermata dan guru dan siswa yang terlibat tidak dianggap anggota penuh dari komunitas sekolah. Guru yang diwawancarai untuk penelitian ini menekankan bahwa paritas bahasa merupakan faktor penting untuk siswa.

Keterlibatan masyarakat dalam konteks ini mengungkapkan kelompok budaya dan ekonomi yang beragam dari orang tua yang merasa mendengar dan kuat didukung oleh sekolah. Salah satu tantangan dalam program bilingual yang terus dihadapi adalah bahwa bahasa Inggris kelas menengah monolingual, orang tua cenderung untuk menarik siswa mereka di kelas tiga karena takut mereka kehilangan pengujian standar. Transfer tersebut, terus-menerus dijelaskan oleh semua kepala sekolah. Dalam penelitian ini, mengakibatkan upaya untuk menambah apa yang salah satunya disebut "comprehensive orangtua komponen pendidikan" untuk program bahasa ganda mereka. Hal ini penting untuk dicatat bahwa sekolah menggunakan strategi inovatif untuk mendukung dan menghormati Bahasa ibu.

mitra Ash-Shibyan: Jurnal Pendidikan dan Konseling | Vol. 04, No. 01 (2021) 


\section{Analisis Penggunaan Bilingual dalam Perkembangan Sosial Anak}

Bermain merupakan suatu kesenangan bagi setiap anak tidak terkecuali pada anak-anak yang mempunyai gangguan fisik dan kemampuan gerak terbatas (Nugraha et al., 2019). Bermain memunculkan unsur kesenangan dalam diri anak yang muncul sebagai bentuk kompetensi sosial anak. Salah satu elemen lain dari kompetensi sosial menurut (Clikeman M, 2007) adalah kemampuan anak untuk mengatur perilakunya sendiri yang mencakup bagaimana anak dapat menyesuaikan diri dengan suatu situasi dan mengubah perilakunya sehingga sesuai dengan lingkungan. Karakteristik anak yang memiliki kompetensi sosial tergambarkan dari jawaban-jawaban anak pada skala kompetensi sosial yang digunakan. Hal ini terlihat dalam beberapa elemen kompetensi sosial yang muncul pada diri anak.

\section{Diagram 1. Korelasi hasil analisis}

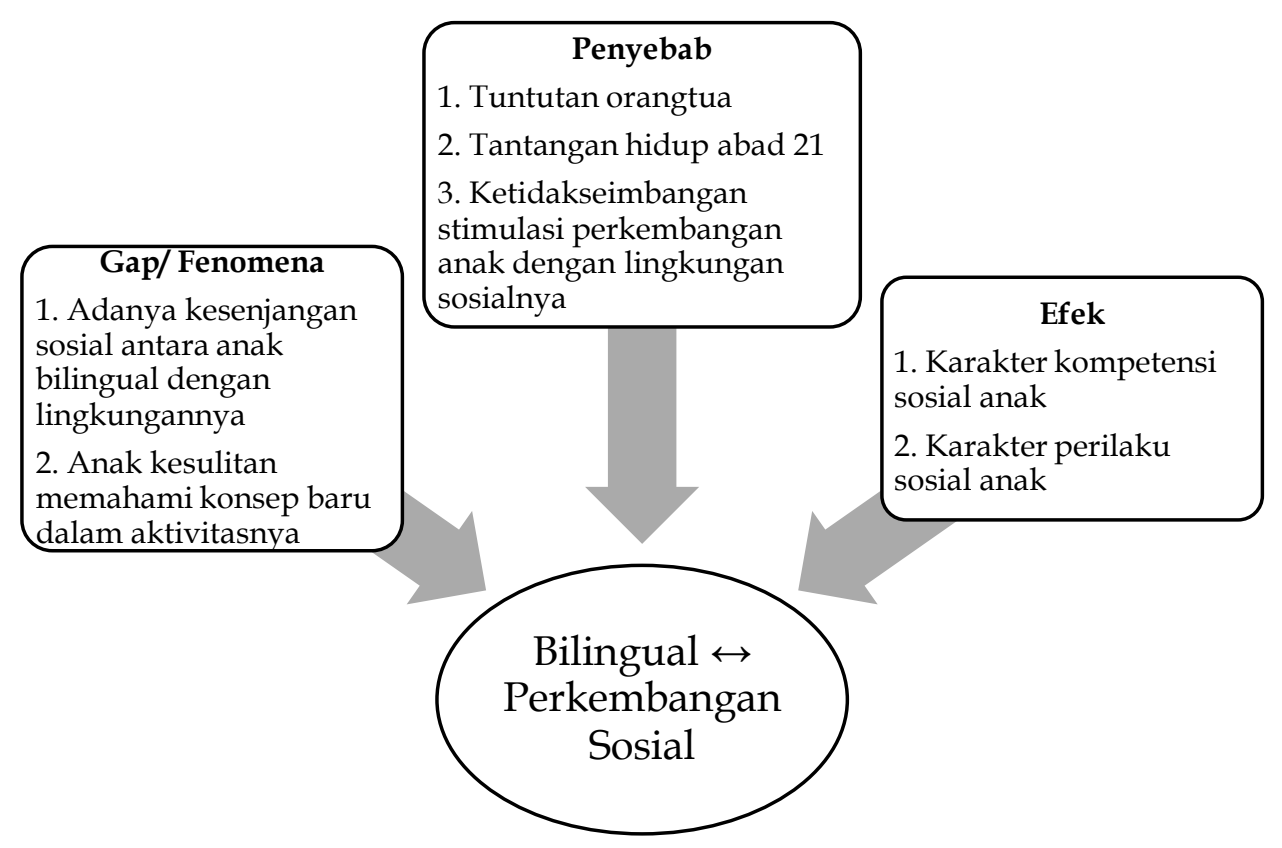

Pada elemen bahasa dan kemampuan untuk berkomunikasi, anak mampu memahami apa yang dimaksudkan oleh teman-temannya dan memahami penjelasan, ucapan dan perintah yang diberikan oleh guru. Dilihat dari elemen kemampuan secara akurat menyampaikan dan menerima pesan emosional, anak akan peduli ketika guru sedang marah. Anak juga memahami isyarat non verbal seperti gerakan-gerakan petunjuk dari guru dan dapat merasakan jika temannya sedang bersedih. 
Dalam elemen kemampuan untuk belajar, anak mampu mengevaluasi perilakunya ketika menghadapi situasi yang sama dengan pengalaman sehingga menghasilkan perubahan perilaku. Anak juga mampu menyadari bahwa perilaku yang ditunjukkannya tidak tepat dan mengetahui konsekuensi dari perilakunya. Pada elemen ke empat yaitu kemampuan untuk mengambil perspektif orang lain, anak mampu menerima perbedaan pendapat dengan teman dan dapat mengikuti saran atau mendengarkan perkataan orang lain.

Dilihat dari elemen kemampuan untuk mengatur perilakunya sendiri, anak mampu menyesuaikan diri dengan tuntutan keadaan di sekitarnya. Anak juga tetap tertib ketika upacara bendera, mampu menahan diri ketika ada orang lain yang mengganggu pada saat jam pelajaran dan menjaga untuk tidak berkelahi di sekolah. Elemen terakhir yakni kemampuan untuk bekerja sama dengan orang lain, anak mampu bernegosiasi dan mampu untuk meminta dengan sopan ketika menginginkan suatu benda. Anak juga merasa bahwa bermain dengan orang lain itu menyenangkan.

Mayoritas anak yang mengikuti sekolah bilingual mampu bersosialisasi dengan orang lain untuk mencapai keinginannya dan senang melakukan suatu kegiatan bersama-sama dengan orang lain untuk mencapai suatu tujuan (Clikeman M, 2007). Hal ini sejalan dengan (Hurlock, 1993) yang menyatakan bahwa anak menunjukkan minat yang tinggi terhadap aktivitas berteman dan berinteraksi dengan teman sebayanya untuk melakukan suatu kegiatan. (Gunarsa, 2004) juga mengemukakan bahwa bermain di usia dini dapat membuat anak lebih mudah untuk menjalin relasi yang baik dengan orang lain. Hal ini juga didukung oleh Landry et al. (2009) mengemukakan hasil penelitiannya bahwa anak yang memiliki kompetensi sosial yang tinggi adalah anak usia sekolah dalam hal joint problem solving task, yaitu kemampuan anak bekerja sama untuk memecahkan suatu masalah dengan teman sebaya dan mengatasi konflik dengan orangtua.

Kategori kompetensi sosial dalam masing-masing elemen juga menunjukkan mayoritas anak pengguna bilingual menunjukkan beberapa karakteristik pada kemampuan untuk mengambil perspektif orang lain. Artinya adalah anak belum dapat memahami apa yang dirasakan dan dipikirkan oleh orang lain dan anak juga masih kurang dapat menyadari bahwa orang lain tidak melihat suatu tindakan serta situasi yang sama

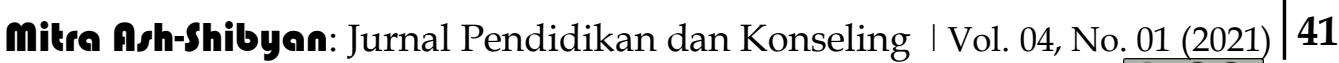


dengannya (Clikeman M, 2007). Hal ini sesuai dengan pandangan Santrock (2002) yang menyatakan bahwa anak-anak memiliki sifat egosentris yang tinggi. Anak lebih cenderung untuk mementingkan dirinya sendiri tanpa memperhatikan pemikiran orang lain yang berbeda dengannya. Selain itu juga Obied (2009) menyatakan bahwa anak bilingual kurang dapat memahami perspektif orang lain terkait dengan perbedaan budaya antar kedua bahasa.

Tak hanya pada kompetensi sosialnya, perkembangan sosial anak bilingual pada konteks perilaku sosial menunjukkan beberapa karakteristik yang cukup menonjol. Salah satu hasil yang positif menurut Andersson (dalam Obied, 2009) anak yang telah mempelajari dua bahasa akan mudah untuk beradaptasi ketika mengunjungi negara lain yang menggunakan bahasa Inggris sebagai alat komunikasinya. Anak yang bilingual akan merasa bangga dengan dirinya karena anak dapat menguasai lebih dari satu bahasa.

Dalam hal berbeda, Bilingual juga memiliki sisi negatif. Dampak bilingualisme dikemukakan oleh Gene (dalam Purba et al., 2016) yang menyatakan bahwa pasti ada kesenjangan sosialisasi antara anak bilingual dengan keluarga besarnya. Kemungkinannya adalah anak akan menganggap rendah bahasa dan budaya orangtuanya karena dari kecil telah diperkenalkan bahasa asing. Pendapat ini diperkuat oleh Tarigan (1988) yang menyatakan kontak anak bilingual dengan keluarga besarnya akan berbeda. Tak sedikit anak yang stres dan tertekan karena dipaksa mengerti bahasa asing. Akibatnya anak akan mengalami kesusahan dalam mengerjakan tugasnya karena ia kurang paham dengan apa yang dijelaskan guru dalam bahasa asing.

Istilah ganda pembelajar bahasa digunakan dalam bidang perawatan dini dan pendidikan untuk menggambarkan anak-anak yang sedang belajar bahasa kedua sementara masih mengembangkan keterampilan dasar dalam bahasa asal mereka (Ballantyne et al., 2008). Istilah ini telah diadopsi oleh Kantor Head Start dan Amerika Serikat Departemen Pendidikan untuk menyoroti kompetensi linguistik anakanak usia 0-5 yang berbicara bahasa lain selain bahasa Inggris (McPhee et al., 2008).

Meskipun manfaat bilingualisme terkenal pada anak-anak (Hakuta, Kenji; Butler, Yuko Goto; Witt, 2000) praktik pendidikan saat ini mencerminkan keyakinan mendalam diadakan dan mitos yang tidak

42 mitra Ash-Shibyan: Jurnal Pendidikan dan Konseling | Vol. 04, No. 01 (2021) Licensed under CC-BY-SA (c) (1) () 
mencerminkan penelitian saat ini (Espinosa, 2013) . Orangtua, pendidik, dan profesional anak usia dini lainnya di Indonesia sering menampilkan pandangan tentang membesarkan anak-anak bilingual karena kepercayaan yang secara bersamaan mengajar bahasa kedua dapat mengakibatkan perkembangan bahasa tertunda atau terganggu dan mengakibatkan anak merasa rendah sosial akan budaya luar (Genesee, 2008).

Banyak penelitian yang mengungkapkan kelebihan dan kelemahan bilingualisme terhadap anak usia dini. Yang diperlu digaris bawahi adalah, sebagai pendidik dan orang tua sebaiknya tidak memaksakan anak untuk menguasai bahasa asing sebagai bahasa kedua mereka. Mengenalkan bahasa asing boleh saja tetapi untuk penguasaan terhadap bahasa tersebut tidak tepat apabila dibebankan kepada anak yang masih dini. Anak usia dini masih belajar memahami dan menguasai bahasa pertama mereka, namun apabila mereka dipaksa untuk menguasai bahasa kedua (bahasa Inggris, Arab, dll) akan menyebabkan anak tidak menguasai konsep bahasa pertama dan konsep bahasa kedua. Selain itu, tidak menutup kemungkinan bahwa anak mungkin akan lebih menyukai budaya dari bahasa kedua daripada bahasa pertamanya. Ini akan menghilangkan kecintaannya terhadap bahasa dan budaya sendiri. Bijaklah dalam memilih stimulasi yang tepat dalam proses tumbuh kembang anak. Menyesuaikan dengan kebutuhan perkembangan, gaya belajar dan usia anak merupakan salah satu hal yang harus dilakukan sebagai bentuk optimalisasi aspek perkembangan anak.

\section{SIMPULAN}

Kemampuan berkomunikasi menjadi salah satu kebutuhan penting anak untuk dapat beradaptasi di abad 21. Bilingual sebagai bentuk stimulasi aspek perkembangan bahasa anak menjadi fenomena yang muncul di masyarakat. Berbagai pro dan kontra dengan latar belakang standar pencapaian perkembangan dan usia anak yang masih terlalu dini mengakibatkan terjadi dilema dalam keseimbangan aspek perkembangan anak khususnya perkembangan sosial.

Berdasarkan analisis dengan melakukan literature review terhadap 20 buku dan artikel ilmiah, ditemukan bahwa penggunaan bilingual pada anak memiliki sisi postitif dan negatif terhadap perkembangan sosial anak. Positifnya, anak pengguna bilingual akan 
mudah beradaptasi di luar lingkungan sosialnya sebagai alat komunikasi. Akan muncul rasa bangga di dalam diri anak karena dapat menguasai lebih dari satu bahasa. Namun negatifnya, sebagian dari anak pengguna bilingual akan kesulitan dalam memahami konsep baru dengan bahasa yang berbeda, hingga tak jarang menjadi merasa tertekan. Selain itu muncul kesenjangan antara anak dengan lingkungan sosialnya.

Orangtua dan pendidik tentunya memiliki harapan yang besar pada anak untuk dapat tumbuh dan berkembang secara optimal. Penggunaan metode yang tepat dalam pengenalan berbagai bahasa pada anak mungkin menjadi alternative solusi agar anak tidak merasa terbebani dalam proses perkembangannya. Selain itu, orangtua dan pendidik juga harus memberikan lingkungan yang mendukung untuk berkembangnya kemampuan anak pengguna bilingual dalam komunikasi maupun aktivitas sosialnya.

\section{UCAPAN TERIMA KASIH}

Terimakasih dan maaf yang tak sempat diutarakan lewat verbal untuk ketua HMPRY tahun 2018-2019, yang telah memberikan motivasi berupa keputusan besar hingga akhirnya saya dapat menyelesaikan tulisan ini.

\section{DAFTAR PUSTAKA}

Annisa, A., \& Sutapa, P. (2019). Scaffolding Strategies to Increase Children Science Interest. 296 (ICSIE 2018), 279-284. https:/ / doi.org/10.2991/icsie-18.2019.50

Annisa, A., \& Sutapa, P. (2019). The Implementation of Nature-based Learning Models to Improve Children's Motor Skills. Jurnal Obsesi : Jurnal Pendidikan Anak Usia Dini, 3(1), 170. https:// doi.org/10.31004/obsesi.v3i1.140

Ballantyne, K. G., Sanderman, A. R., \& Levy, J. (2008). Educating English language learners: Building teacher capacity. National Clearinghouse for English Language Acquisition \& Language Instruction Educational Programs. http://www.ncela.gwu.edu/practice/mainstream_teachers.htm

Chaer, A., \& Agustina, L. (1995). Sosiolinguistik Perkenalan Awal. Rineka Cipta.

Elliot, S. N., \& Gresham, F. M. (1987). Children's Social Skills: Assessment and Classification Practices. Journal of Counseling \& Development, 66(2), 96-99. https://doi.org/10.1002/j.1556-6676.1987.tb00808.x

Espinosa, L. M. (2013). Early education for dual language learners: Promoting school readiness and early school success. National Center on Immigrant Integration Policy, Migration Policy Institute.

Fillmore, L. W. (2012). When learning a second language means losing the first. The New Immigration: An Interdisciplinary Reader, 346, 289-307. 


\section{https://doi.org/10.4324/9780203621028-23}

Genesee, F. (2008). Early dual language learning. Zero to Three, 29(1), 17-23.

Gresham, F. M., Van Bao, M., \& Cook, C. R. (2006). Social skills training for teaching replacement behaviors: Remediating acquisition deficits in at-risk students. Behavioral Disorders, 31(4), 363-377. https://doi.org/10.1177/019874290603100402

Gunarsa, S. Y. S. D. G. (2004). Psikologi perkembangan anak dan remaja.

Hakuta, Kenji; Butler, Yuko Goto; Witt, D. (2000). How Long Does It Take To Have English Proficiency.

Han, E. S., \& Goleman, Daniel; Boyatzis, Richard; Mckee, A. (2019). Social Behavior and Skills in Children. Journal of Chemical Information and Modeling, 53(9).

Hurlock, E. B. (1993). Psikologi perkembangan anak jilid 2. Erlangga.

Hurlock, Elizabeth . B. (1978). Child growth and development. McGraw-Hill Education.

Landry, S. H., Smith, K. E., \& Swank, P. R. (2009). New directions in evaluating social problem solving in childhood: early precursors and links to adolescent social competence. New Directions for Child and Adolescent Development, 2009(123), 51-68. https://doi.org/10.1002/cd.235

Matson, J. L., Wilkins, J., Sevin, J. A., Knight, C., Boisjoli, J. A., \& Sharp, B. (2009). Reliability and item content of the Baby and Infant Screen for Children with autism Traits (BISCUIT): Parts 1-3. Research in Autism Spectrum Disorders, 3(2), 336-344. https:// doi.org/10.1016/j.rasd.2008.08.001

McFall, R. M. (1982). A review and reformulation of the concept of social skills. Behavioral Assessment.

McPhee, N. F., Ohs, B., \& Hutchison, T. (2008). Semantic building blocks in genetic programming. Lecture Notes in Computer Science (Including Subseries Lecture Notes in Artificial Intelligence and Lecture Notes in Bioinformatics), 4971 LNCS, 134-145. https://doi.org/10.1007/978-3-540-78671-9_12

Nugraha, A., Sukoco, P., \& Annisa, A. (2019). Motivation and Physical Education Learning Achievement among Students with Hearing Impairment. Acta Facultatis Educationis Physicae Universitatis Comenianae, 59(2), 129-137. https://doi.org/10.2478/afepuc-2019-0011

Obied, V. M. (2009). How do siblings shape the language environment in bilingual families? International Journal of Bilingual Education and Bilingualism, 12(6), 705-720. https:// doi.org/10.1080/13670050802699485

Purba, L. V., Yurliani, R., \& Utara, U. S. (2016). Gambaran kompetensi sosial pada anak yang mengikuti sekolah bilingual. http://prosiding.ikatanpsikologisosial.org/index.php/Prosiding2015/articl e/view $/ 4$

Putallaz, M., \& Sheppard, B. H. (1995). 12 Conflict management and social competence. Conflict in child and adolescent development.

Santrock, J. W. (2002). Life-span development.

Semrud-Clikeman M. (2007). Social Competence in Children. Contemporary Psychology: A Journal of Reviews, 33(9), 835-835. https://doi.org/10.1037/026076

Szecsi, T. (2005). Embracing languages and cultures in the magic preschool, Moscow. 
Childhood Education. 82(2), 98-B.

Tarsidi, D. (2009). Dampak Ketunaan pada Pembelajar Bahasa.

Vaughn, S., Hogan, A., Kouzekanani, K., \& Shapiro, S. (1990). Peer Acceptance, Self-Perceptions, and Social Skills of Learning Disabled Students Prior to Identification. Journal of Educational Psychology, 82(1), 101-106. https:// doi.org/10.1037/0022-0663.82.1.101

46 mitra Ash-Shibyan: Jurnal Pendidikan dan Konseling | Vol. 04, No. 01 (2021) Licensed under CC-BY-SA (c) (1) () 